\title{
Chicken Meat Submitted to Gamma Radiation and Packed with or without Oxygen
}

http://dx.doi.org/10.1590/1516-635x1702255-262

\section{Euthor(s)}

Pelicia $\mathrm{K}^{\prime}$

Garcia EA"

Molino $A B^{\prime \prime}$

Santos GCIII

Vieira Filho JA"I

Santos TA ${ }^{\prime \prime \prime}$

Berto DA III

Ph.D., Associate Professor of the Department of Animal Production, DZO/ UNEMAT. Pontes e Lacerda, MT, Brazil

" Ph.D., Head Professor of the Department of Animal Production, FMVZ/UNESP. Botucatu, SP, Brazil

III Students of the Post-Graduation Program in Animal Science of FMVZ/UNESP. Botucatu, SP, Brazil

\section{ABSTRACT}

The objective of this study was to evaluate the effects on gamma radiation levels on the physical and microbiological characteristics of chicken breast meat. A completely randomized experimental design in a $4 \times 2 \times 3$ factorial arrangement was adopted. Treatments consisted of four radiation concentrations $(0,2,4$, or $8 k G y)$, two package sealing methods (with or without vacuum), and three storage times $(01,07$, or 14 days), with ten replicates each, totaling 240 chicken breast fillets. Packaging and radiation had no influence ( $p>0.05)$ on chicken breast meat $\mathrm{pH}$, water retention capacity, or presence of Salmonella spp. Breast fillets not submitted to radiation and vacuum packed presented higher water retention capacity $(p<0.05)$ than those radiated at $4 \mathrm{kGy}$ and vacuum packed. Drip loss in fillets radiated at $8 \mathrm{kGy}$ and not vacuum packed was higher $(p<0.05)$ than in non-radiated and non-vacuum packed fillets; however, both were not different from the other treatments. Coliform presence increased with storage time in non-radiated samples; however, when these were vacuum-packed, their development was slower. The results of the present experiment suggest that the use of a low radiation dose $(2 \mathrm{kGy})$, combined with vacuum packing, may minimize the harmful effects of storage on chicken breast fillets.

\section{INTRODUCTION}

Corresponding author e-mail address Pelícia K

Departamento de Zootecnia $\mathrm{Br} 174$ - Km 209 - Pontes e Lacerda - MT - 78250000 - Brazil

E-mail: kleber.pelicia@unemat.br

\section{- Keywords}

Poultry production, vacuum preservation, storage period, ionizing radiation.
Brazil produced 12.7 million tons of chicken meat in 2012, and increased its exports in around one million tons between 2004 and 2012 (Anuário da Avicultura Industrial Brasileira, 2013).

Therefore, products with consistent quality and safety standards should be offered to the consumers to maintain this market position. In order to keep our competitiveness and expansion in the chicken meat market, storage and preservation methods must be improved, supplying meat with adequate quality standards, long shelf life and widely accepted by the consumers.

Microorganism growth and enzyme activity are the main factors that limit chicken meat shelf life, which may be extended, however, if protected by packages and submitted to decontamination.

Radiation is a very interesting technology, as it efficiently reduces most of the problems caused particularly by microbial spoilage and by the use of chemical substances that pose potential health risks, thereby reducing the risks of foodborne disease outbreaks.

In this context, the aim of this study was to evaluate the effects on gamma radiation levels on the physical and microbiological characteristics of chicken breast meat. 


\section{THEORETICAL BACKGROUND}

\section{Chicken meat quality}

Due to the need of supplying safe products to final consumers, technologies that increase food shelf life have become increasingly important, including radiation. Consumers are currently more demanding when choosing food products, and are interested in new technologies. According to Ornellas et al. (2006), the lack of accurate information limits the expansion of food radiation.

\section{Radiation}

Food preservation using radiation consists in treating food products with electromagnetic energy with the aim of preserving those products by reducing or eliminating their microbial load, particularly of microbes that are harmful to human health.

The advantages of gamma radiation relative to other methods used to destroy bacteria in foods are its high energy content, extensive penetration, and lethality, because it acts at cell level. Its penetration is immediate, uniform, and deep (Baptista et al., 2014). Gamma rays are short-length waves, similar to ultraviolet light (UV) and to microwaves, and are produced by radioactive isotopes, such as cobalt 60 (60Co) and cesium 137 (137Cs) (Spolaore et al., 2001).

When ionizing radiation penetrates the food, part of its energy is absorbed, and the quantity of radiation that penetrates the exposed product mass is called "absorbed dose." Radiation doses are expressed in kiloGrays (kGy) or Grays (Gy), a unit corresponding to the absorption of one Joule of energy per $\mathrm{kg}$ of matter (Torgby-Tetteh et al., 2014). Depending on the ionizing radiation dose to which food is submitted, the process is called radurization, radicidation, or radappertization.

Radurization is considered similar to pasteurization, as it reduces the counts of viable spoilage microorganisms. In this case, other preservation methods also need to be used, such as refrigeration. Radiation doses between 0.4 and $2.5 \mathrm{kGy}$ are applied. Radurization can be used to prevent bulb and tuber sprouting, delay fruit maturation, prevent fungal spoilage of fruits and vegetables, and to control insect and mite infestation (Gallas et al., 2009; Franco \& Landgraf, 2005).

Radicidation is the treatment of foods with an ionizing energy dose sufficient to reduce viable and non-spore forming pathogenic bacteria to numbers below those detected by bacteriological analysis methods. This dose also inactivates parasites possibly present in foods. The doses used for radicidation are typically between 2 and 8kGy (IAEA, 2002). This method is applied in fruit juices, fresh meat, and fresh pasta.

Radappertization or sterilization is the treatment of foods with an ionizing energy dose sufficient to prevent decomposition and toxicity of microbial origin, independently of storage time and conditions, provided the food was not previously contaminated. The doses used are generally between 25 and 45kGy (IAEA, 2002). This method is applied by the US space agency NASA in meat products (CNEA, 2011), such as chicken and turkey breasts. Foods submitted to this method do not have an expiration date, even under room temperature, as long as the package is intact. The Laboratory of Food Radiation and Radioentomology of the Brazilian Council of Atomic Energy (CNEA) has researched this technique for the preservation of chicken meat.

According to Mantilla et al. (2012a), the application of doses that are considered low, i.e., lower than 10kGy, aim at extending food shelf life by reducing the microbial population initially present in the product and are used for fresh meat, particularly for poultry products.

The radiation doses recommended are 3 to $5 \mathrm{kGy}$ for frozen chicken meat and $1.5 \mathrm{kGy}$ for refrigerated meat. These doses are effective for the reduction of pathogens, such as Salmonella spp (Arzina et al., 2012; Henriques et al., 2013). The Codex Alimentarius (2010) states that the radiation dose applied should be sufficient to increase the product shelf life and to eliminate pathogenic microorganisms, especially Salmonella. The recommended dose to extend the shelf life and to promote decontamination of chicken meat is 7kGy (Sarwar et al., 2014).

In the USA, minimum and maximum doses of 1.5 and 3 kGy, respectively, are established for chicken meat. Brazilian legislation follows the international recommendations of the United Nations bodies Food and Agriculture Organization (FAO), International Atomic Energy Agency (IAEA), and Codex Alimentarius. The current regulations for the application of radiation in foods are described in Resolution n. 21 (BRASIL, 2001). This resolution establishes that any food product may be radiated, provided minimum and maximum dose limits are complied with. The minimum dose must be sufficient to achieve the intended purpose, and the maximum dose must be lower than the dose that may compromise the functional properties or sensorial attributes of that food.

The radiation process is influenced both by external factors (temperature, presence or absence of oxygen, subsequent storage conditions) and by inherent food 
factors (physical state, density, moisture content, etc.). This is why there are specific procedures, including different radiation doses, for each product (Cena, 2006; Mahapatra, 2005).

\section{Vacuum packing}

In vacuum packing, air is removed from gasimpermeable packages, which are immediately sealed. During storage of vacuum-packed foods, carbon dioxide $\left(\mathrm{CO}_{2}\right)$ level increases as a result of tissue and microorganism respiration (Gallas et al., 2009). According to Gallas et al. (2009), $\mathrm{CO}_{2}$ is produced by microorganisms, because tissue anaerobic metabolism produces mainly lactic acid. In this packing technique, carbon dioxide $\left(\mathrm{CO}_{2}\right)$ concentration rapidly increases in 10 to $20 \%$ during the first four hours, reaching a maximum level of approximately $30 \%$. At the same time, oxygen level is reduced to $1-3 \%$ due to the activity of meat enzymes. This modified gas environment hinders the development of rapidly-growing mesophilic heterotrophic aerobes and stimulates the growth of slow-growing lactobacilli. The shelf life of vacuumpacked meats in gas-impermeable packages is much longer compared with meats packed in the presence of atmospheric air (Oluwafemi, 2013).

The lack of oxygen inhibits spoilage, consequently enhancing product quality and shelf life. However, vacuum-packed food will eventually be spoiled by the presence of anaerobic and microaerophilic microorganisms and due to non-oxidative reactions, which may be minimized by cold storage. Also, compression is unavoidable, which makes vacuumpacking inadequate for many products (Novaes, 2009).

\section{MATERIALS AND METHODS}

\section{Location}

A total number of 240 skinless and deboned chicken breasts were acquired from a processing plant.

Chicken breasts were radiated at Companhia Brasileira de Esterilização, located in Jarinu, SP, Brazil. The meat was then transported in insulated boxes to the Food Analysis Laboratory of Universidade José do Rosário Vellano (UNIFENAS/ FETA), Alfenas, MG, Brazil, where it was submitted to physical and microbiological analyses.

\section{Experimental design}

A completely randomized $(4 \times 2 \times 3)$ experimental design was adopted. Treatments consisted of four radiation concentrations $(0,2,4$, or $8 k G y)$, two package sealing methods (with or without vacuum), and three storage times $(01,07$, or 14 days), with ten replicates each, totaling 240 chicken breast fillets.

\section{Meat radiation}

Samples weighing $100 \mathrm{~g}$ were collected from all replicates. Samples were individually placed in plastic bags, and half was packed using vacuum and half without vacuum.

Packed samples were maintained in insulated bags with dry ice until radiation. Meat samples were submitted to the following radiation doses: OkGy (not radiated), 2kGy, 4kGy, and 8kGy. Samples were then maintained in a cold chamber at $2{ }^{\circ} \mathrm{C}$ until analyses after one, seven, and 14 days of storage.

\section{Evaluated parameters}

Before analyses, half (five) of the samples of each replicate was weighed to determine meat physical characteristics and the other half was submitted to the Microbiology Laboratory.

\section{Physical parameters}

Drip loss, pH, water holding capacity and water absorption capacity. Drip loss was calculated as the percentage of sample weight loss after storage (Zhuang \& Savage, 2012). Meat pH was measured using a pHmeter (Sentron, model 1001) coupled to a fine-tip penetration probe (Sentron type LanceFET, model 1074001).

Water holding capacity was measured according to the method described by Kissel (2009), in which pressure is applied $(10 \mathrm{~kg} / 5 \mathrm{~min})$ on the tissue and the water released is measured. Water absorption capacity was determined by adding $90 \mathrm{~mL}$ distilled water to $30 \mathrm{~g}$ of ground meat and collecting $35 \mathrm{~g}$ of the obtained paste, which was centrifuged for 15min at 3000rpm. The supernatant was discarded and the tube was weighed. Water absorption capacity was calculated as:

$$
\% W A C=\{[(P W-M W)-S W] / P C\} * 100
$$

where $\mathrm{PW}=$ paste weight; $\mathrm{MW}=$ meat weight in the paste; and SW = supernatant weight (Roça, 1986).

\section{Microbiological analyses}

Bacteriological analyses were carried out at the Microorganism Biology and Physiology Laboratory of Universidade José do Rosário Vellano (Unifenas), Alfenas, MG, according to ANVISA resolution RDC $\mathrm{n}$. 12 and as described by Silva et al. (2007).

The presence of Salmonella spp was tested by homogenizing $25 \mathrm{~g}$ of meat from each replicate with 
$225 \mathrm{~mL}$ of lactose broth, incubating the tubes at $35^{\circ} \mathrm{C}$ for $24 \mathrm{~h}$, and then transferring $1 \mathrm{~mL}$ of this solution to $9 \mathrm{~mL}$ tetrathionate brilliant green broth and $1 \mathrm{~mL}$ to $9 \mathrm{~mL}$ selenite cystine broth, followed by incubation at $42^{\circ} \mathrm{C}$ for $24 \mathrm{~h}$. Samples were then seeded on to SalmonellaShigella agar and Hektoen agar plates. Suspect typical colonies were seeded on triple sugar iron and lysine iron agar slants, which were incubated at $35^{\circ} \mathrm{C}$ for 24h. Salmonella-suspected colonies were submitted to biochemical tests (VM, VP, and indole broth and Simmons citrate agar), according to Silva, Junqueira, and Silveira (2007).

Total coliforms were determined using the most probable number (MPN) index. Samples were homogenized and serially diluted in lactose broth at $10^{-1}$ to $10^{-3}$. One $\mathrm{mL}$ of each dilution was inoculated, in triplicate, in lauryl sulfate triptose (LST) broth and incubated at $35^{\circ} \mathrm{C}$ for $24 \mathrm{~h}$. Presumably positive samples, i.e., those producing turbidity and gas in Durham tubes, were plated for confirmation in brilliant green bile broth at $2 \%$ and incubated at $35^{\circ} \mathrm{C}$ for $24 \mathrm{~h}$.

Fecal coliform MPN were determined by reseeding LST-positive samples in EC (E. coli) broth in triplicate per dilution. Samples were incubated at $45^{\circ} \mathrm{C}$ for $24 \mathrm{~h}$, and then submitted to the following biochemical tests: indole, methyl red, Voges-Proskauer, and citrate.

\section{Statistical analyses}

Data were analyzed using the General Linear Model (GLM) procedures of SAS statistical package (SAS Institute, 2001), and means were compared by the test of Tukey-Kramer.

\section{RESULTS}

There was no influence $(p>0.05)$ of radiation or packing method (with or without vacuum) on drip loss, pH, water holding capacity, or water absorption capacity of the evaluated chicken breast meat samples after one day of storage (Table 1).

There was no influence $(p>0.05)$ of radiation or packing method (with or without vacuum) on drip loss, $\mathrm{pH}$, or water holding capacity of the evaluated chicken breast meat after seven days of storage (Table 2 ). The chicken breast fillets that were not radiated and vacuum-packed absorbed more water $(p<0.05)$ than those radiated at $4 \mathrm{kGy}$ and vacuum-packed; however, they were not different from the other treatments.

There was no influence $(p>0.05)$ of radiation or packing method (with or without vacuum) on $\mathrm{pH}$, water holding capacity, or water absorption capacity of the evaluated chicken breast meat after 14 days of storage (Table 3). Drip loss in fillets radiated with 8kGy and not vacuum packed was lower $(p<0.05)$ than in the fillets that were not radiated and not vacuum packed; however, neither were statistically different from the other treatments.

Chouliara et al. (2008) mentioned that chicken meat radiated at doses higher than $4 \mathrm{kGy}$ present higher drip loss. However, in the present study it was observed that drip loss was lower in the samples treated at higher radiation doses after 14 days of storage. Xiao et al. (2011) obtained lower water holding capacity when chicken thighs were treated with radiation. Damage to the structural integrity of the muscle fiber membrane causes meat to reduce its water holding

Table 1 - Effect of gamma radiation and package-sealing method (with or without vacuum) on the physical characteristics of chicken breast meat after one day of storage.

\begin{tabular}{|c|c|c|c|c|}
\hline Treatment & DL & WAC & $\mathrm{pH}$ & WHC \\
\hline OkGy radiation + vacuum packing & 3.43 & 29.32 & 5.75 & 83.54 \\
\hline $2 \mathrm{kGy}$ radiation + vacuum packing & 3.39 & 29.68 & 5.83 & 86.55 \\
\hline 4kGy radiation + vacuum packing & 3.41 & 29.60 & 5.68 & 83.84 \\
\hline $8 \mathrm{kGy}$ radiation + vacuum packing & 3.40 & 30.67 & 5.72 & 85.76 \\
\hline OkGy radiation + packing with no vacuum & 3.37 & 30.80 & 5.79 & 87.08 \\
\hline $2 k$ Gy radiation + packing with no vacuum & 3.37 & 30.90 & 5.70 & 85.14 \\
\hline $4 k G y$ radiation + packing with no vacuum & 3.35 & 28.20 & 5.79 & 84.85 \\
\hline $8 k G y$ radiation + packing with no vacuum & 3.36 & 29.10 & 5.83 & 87.00 \\
\hline Mean & 3.43 & 29.78 & 5.76 & 85.45 \\
\hline CV & 1.33 & 4.63 & 1.35 & 4.72 \\
\hline
\end{tabular}

Gray (Gy) or kiloGray (kGy): measurement unit in which one Gray is equivalent to one Joule of energy per kilogram of radiated food. Means followed by different letters in the same column are significantly different $(\mathrm{p}<0.05)$. DL $=$ drip loss; $\mathrm{WAC}=$ water absorption capacity; $\mathrm{WHC}=$ water holding capacity. 
Table 2 - Effect of gamma radiation and package-sealing method (with or without vacuum) on the physical characteristics of chicken breast meat after seven days of storage.

\begin{tabular}{lllll}
\hline Treatment & $\mathrm{DL}$ & $\mathrm{WAC}$ & $\mathrm{pH}$ & $\mathrm{WHC}$ \\
\hline OkGy radiation + vacuum packing & 11.34 & $31.02 \mathrm{a}$ & 5.90 & 95.12 \\
\hline 2kGy radiation + vacuum packing & 11.78 & $30.26 \mathrm{ab}$ & 5.87 & 93.34 \\
\hline 4kGy radiation + vacuum packing & 13.80 & $28.94 \mathrm{~b}$ & 5.79 & 99.80 \\
\hline 8kGy radiation + vacuum packing & 12.40 & $30.58 \mathrm{ab}$ & 5.94 & 97.60 \\
\hline OkGy radiation + packing with no vacuum & & & & \\
\hline 2kGy radiation + packing with no vacuum & 16.62 & $30.74 \mathrm{ab}$ & 5.89 & 95.42 \\
\hline 4kGy radiation + packing with no vacuum & 13.34 & $30.72 \mathrm{ab}$ & 5.88 & 97.90 \\
\hline 8kGy radiation + packing with no vacuum & 15.62 & $30.28 \mathrm{ab}$ & 5.84 & 97.86 \\
\hline Mean & 11.52 & $29.92 \mathrm{ab}$ & 5.80 & 92.56 \\
\hline CV & 13.30 & 30.31 & 5.87 & 95.95 \\
\hline
\end{tabular}

Gray (Gy) or kiloGray (kGy): measurement unit in which one Gray is equivalent to one Joule of energy per kilogram of radiated food. Means followed by different letters in the same column are significantly different $(\mathrm{p}<0.05)$. $\mathrm{DL}=$ drip loss; $\mathrm{WAC}=$ water absorption capacity; $\mathrm{WHC}=$ water holding capacity.

capacity (Petracci \& Cavani, 2012; Ahn, 2013). For instance, Leonel (2008) radiated chicken meat with doses up to $3 k$ Gy and did not observe any effect on meat water holding capacity; however, it was reduced up to four months of storage and increased again after six months. Damage to the structural integrity of muscle fibers may also reduce meat water absorption capacity, as observed in the vacuum-packed chicken breast meat radiated with $4 \mathrm{kG}$ and stored for seven days compared with the non-radiated and vacuumpacked samples after the same storage period.

Meat $\mathrm{pH}$ was not different among treatments, probably because the period of rigor mortis was already completed when samples were collected.
Meat $\mathrm{pH}$ lowers post mortem due to the breakdown of glycogen, producing lactic acid, which accumulates in the muscle, thereby reducing its $\mathrm{pH}$. Leonel (2008) also did not observe any effect of radiation on chicken meat $\mathrm{pH}$.

The presence of Salmonella spp was not detected in none of the $12 \mathrm{~g}$ samples after 14 days of storage. The lack of detection of Salmonella in the present study is probably due to the absence of Salmonella in the meat batches collected in the processing plant. In the study of Al-Bachir et al. (2010), 4kGy radiation was sufficient to achieve microbiological level accepted by the official authorities. However, in another study with ground chicken breast meat, the best microbiological

Table 3 - Effect of gamma radiation and package-sealing method (with or without vacuum) on the physical characteristics of chicken breast meat after 14 days of storage.

\begin{tabular}{|c|c|c|c|c|}
\hline Treatment & $\mathrm{DL}$ & WAC & $\mathrm{pH}$ & WHC \\
\hline OkGy radiation + vacuum packing & 14.70ab & 30.40 & 5.79 & 96.40 \\
\hline 2 kGy radiation + vacuum packing & $13.02 \mathrm{ab}$ & 29.48 & 5.74 & 95.26 \\
\hline 4kGy radiation + vacuum packing & $13.06 a b$ & 29.38 & 5.70 & 99.86 \\
\hline $8 k$ Gy radiation + vacuum packing & $12.01 \mathrm{ab}$ & 30.00 & 5.71 & 95.88 \\
\hline OkGy radiation + packing with no vacuum & $17.54 a$ & 30.88 & 5.70 & 97.54 \\
\hline 2 kGy radiation + packing with no vacuum & $14.42 \mathrm{ab}$ & 31.06 & 5.89 & 95.30 \\
\hline 4kGy radiation + packing with no vacuum & $15.42 \mathrm{ab}$ & 30.58 & 5.76 & 97.92 \\
\hline 8kGy radiation + packing with no vacuum & $9.08 \mathrm{~b}$ & 29.70 & 5.87 & 93.80 \\
\hline Mean & 13.68 & 30.19 & 5.77 & 96.51 \\
\hline$C V$ & 3.20 & 4.48 & 2.84 & 3.69 \\
\hline
\end{tabular}

Gray (Gy) or kiloGray (kGy): measurement unit in which one Gray is equivalent to one Joule of energy per kilogram of radiated food. Means followed by different letters in the same column are significantly different $(p<0.05)$. $\mathrm{DL}=$ drip loss; $W A C=$ water absorption capacity; $W H C=$ water holding capacity. 
Table 4 - Effect of gamma radiation and package-sealing method (with or without vacuum) on total and fecal coliform counts (MPN) in chicken breast meat after 14 days of storage.

\begin{tabular}{|c|c|c|}
\hline Treatment & $\begin{array}{l}\text { Total coliforms } \\
\text { (MPN/g) }\end{array}$ & $\begin{array}{l}\text { Fecal coliforms } \\
\text { (MPN/g) }\end{array}$ \\
\hline & \multicolumn{2}{|c|}{1 day of storage } \\
\hline OkGy radiation + vacuum packing & 8.1 & 8.1 \\
\hline 2 kGy radiation + vacuum packing & 0 & 0 \\
\hline 4kGy radiation + vacuum packing & 0 & 0 \\
\hline 8kGy radiation + vacuum packing & 0 & 0 \\
\hline OkGy radiation + packing with no vacuum & 7.8 & 7.8 \\
\hline $2 k$ ky radiation + packing with no vacuum & 0 & 0 \\
\hline 4kGy radiation + packing with no vacuum & 0 & 0 \\
\hline \multirow[t]{2}{*}{ 8kGy radiation + packing with no vacuum } & 0 & 0 \\
\hline & \multicolumn{2}{|c|}{7 days of storage } \\
\hline OkGy radiation + vacuum packing & 14.3 & 14.3 \\
\hline $2 \mathrm{kGy}$ radiation + vacuum packing & 0 & 0 \\
\hline 4kGy radiation + vacuum packing & 0 & 0 \\
\hline 8kGy radiation + vacuum packing & 0 & 0 \\
\hline OkGy radiation + packing with no vacuum & 15.2 & 15.2 \\
\hline 2 kGy radiation + packing with no vacuum & 0 & 0 \\
\hline 4kGy radiation + packing with no vacuum & 0 & 0 \\
\hline \multirow[t]{2}{*}{ 8kGy radiation + packing with no vacuum } & 0 & 0 \\
\hline & \multicolumn{2}{|c|}{14 days of storage } \\
\hline OkGy radiation + vacuum packing & 16.8 & 16.8 \\
\hline 2 kGy radiation + vacuum packing & 0 & 0 \\
\hline 4kGy radiation + vacuum packing & 0 & 0 \\
\hline 8kGy radiation + vacuum packing & 0 & 0 \\
\hline OkGy radiation + packing with no vacuum & 18.5 & 18.5 \\
\hline $2 k$ ky radiation + packing with no vacuum & 0 & 0 \\
\hline 4kGy radiation + packing with no vacuum & 0 & 0 \\
\hline 8kGy radiation + packing with no vacuum & 0 & 0 \\
\hline
\end{tabular}

$\mathrm{MPN}=$ most probable number.

results were obtained with 6kGy (Al-Bachir, 2013). These results show that low radiation doses can be efficiently used to control pathogens in chicken meat. The recommended radiation doses for frozen chicken meat are 3-5kGy, and 1.5-2.5kGy for refrigerated meat that will be consumed within a short period of time (Arzina et al., 2012; Henriques et al., 2013)

The results demonstrate the presence of total and fecal coliforms only in the samples that were not radiated, independently of packing method and storage time (Table 4). Therefore all the evaluated radiation doses $(2,4$, and $8 \mathrm{kGy})$ were sufficient to eliminate total and fecal coliforms in the meat samples. Some authors (Torgby-Tetteh et al., 2014) state that ionizing radiation destroys microorganisms by damaging their DNA.
Despite being found in non-radiated samples, total and fecal coliform counts were reduced with storage time when samples were vacuum packed (with no oxygen). Microorganism growth and replication are influenced by $\mathrm{pH}$, humidity, temperature, and oxygen, which is required for coliform growth (Mantilla et al., 2012b).

Finally, it should be mentioned that, although all samples belonged to the same batch, those that were not submitted to radiation presented total and fecal coliform contamination. Also, the lowest radiation dose (2kGy) eliminated those microorganisms without any effect on meat physical characteristics. It was also found that vacuum packing in the absence of radiation did not favor total and fecal coliform development due to the absence of oxygen.

\section{CONCLUSION}

The results of the present experiment suggest that the use of a low radiation dose (2kGy), combined with vacuum packing, may minimize the harmful effects of storage on chicken breast fillets.

\section{ACKNOWLEDGEMENTS}

The authors thank Companhia Brasileira de Esterilização (CBE), in Jarinu, SP, Brazil, for radiating the meat samples.

\section{REFERENCES}

Ahn DU, Kim IS, Lee EJ. Irradiation and additive combinations on the pathogen reduction and quality of poultry meat. Poultry Science 2013;92(2): 534-545.

Al-Bachir M, Othman Y. "Use of irradiation to control microorganisms and extend the refrigerated market life of chicken sausage". Innovative Romanian Food Biotechnology 2013;13: 63-70.

Al-Bachir M, Farah S, Othman Y. Influence of gamma irradiation and storage on the microbial load, chemical and sensory quality of chicken kabab. Radiation Physics and Chemistry 2010;79: 90-905.

Arzina $\mathrm{H}$, Hasan MZ, Al-mahin A, Rashid HO. Effect of the radiation and low temperature on pathogenic Staphylococcus aureus isolated from pizza. American Journal of Food Technology 2012; 7:204-213.

Avicultura Industrial: anuário 2013. Mercado de frango é marcado por custos altos e preços recordes em 2012. São Paulo: Gessulli; 2013. v.104, n.11. p.54-61. 
Baptista RF, Lemos M, Vital HC, Carneiro CE, Mársio ET, Conte Jr CA, Mano SB. Microbiological quality and biogenic amines in ready-to-eat grilled chicken fillets under vacuum packing, freezing, and high-dose irradiation. Poultry Science 2014;93 (6): 1571-1577.

BRASIL. Resolução RDC n.21, de 26 de janeiro 2001. Agência Nacional de Vigilância Sanitária aprova o regulamento técnico para irradiação de alimentos. Diário Oficial da União, Brasília, DF, n.20-E, 29 jan. 2001. Seção 1, p.35.

CENA- Centro de Energia Nuclear na Agricultura. Desenvolvido pela USPCENA/PCLQ, 2002-2006. Apresenta textos sobre a divulgação da tecnologia de irradiação de alimentos e outros materiais [cited 2011 Ago 20]. Available from: http://www.cena.usp.br/irradiacao/index.asp.

Chouliara E, Badeka A, Savvaidis I, Kontominas MG. Combined effect of irradiation and modified atmosphere packaging on shelf-life extension of chicken breast meat: microbiological, chemical and sensory changes. European Food Research and Technology February 2008;226(4): 877888.

CNEA- Conselho Nacional de Energia Atómica. Apresenta textos sobre irradiação de alimentos [cited 2011 Set 7]. Available from: http:// caebis.cnea.gov.ar/aplicaciones/alim//rra1.html\#Definicion.

Codex Alimentarius Commission. Procedural manual. 9th ed. Rome: FAO/ WHO; 2010. 183p.

Franco BDGM, Landgraf M. Microbiologia dos Alimentos. São Paulo: Atheneu; 2005. 182p.

IAEA- International Atomic Energy Agency. Dosimetry for food irradiation. Vienna; 2002. 161p.

Henriques LSV, Henry FDC, Barbosa JB, Ladeira SA, Pereira SMDF, Antonio IMDS, Reis EMFD. Elimination of coliforms and Salmonella spp. in sheep meat by gamma irradiation treatment. Brazilian Journal of Microbiology 2013;44(4):1147-1153.

Kissel C, Soares AL, Rossa A, Shimokomaki M. Functional properties of PSE (Pale, Soft, Exudative) broiler meat in the production of mortadella [online]. Brazilian Archives Biology Technology 2009;52:213-217 .

Leonel FR. Irradiação e qualidade da carne de frango congelada e embalada a vácuo [tese]. Jaboticabal (SP): Universidade Estadual Paulista; 2008.

Mahapatra AK, Muthukumarappan K, Julson JL. Applications of Ozone, Bacteriocins and Irradiation in Food Processing: a Review. Critical Reviews in Food Science and Nutrition 2005; 45:447-461.

Mantilla SPS, Santos EB, Freitas MQ, Vital HC, Mano SB, Franc RM Refrigerated poultry breast fillets packed in modified atmosphere and irradiated: bacteriological evaluation, shelf life and sensory acceptance. Brazilian Journal of Microbiology 2012a;43(4):1385-1393.

Mantilla SPS. Refrigerated poultry breast fillets packed in modified atmosphere and irradiated: bacteriological evaluation, shelf life and sensory acceptance. Brazilian Journal of Microbiology 2012b;43(4):1385-1392

Novaes SF, Conte-Junior CA, Franco RM, Mano SB. Influência das novas tecnologias de conservação sobre os alimentos de origem animal. Revista Científica Eletrônica de Medicina Veterinária 2012;9(19):1-21.

Oluwafemi RA, Edugbo OM, Solanke EO, Akinyeye AJ. Meat quality, nutrition security and public health: a review of beef processing practices in Nigeria. African Journal of Food Science and Technology 2013;4(5): 96-99.

Ornellas CBD, Gonçalves MPJ, Silva PR, Martins RT. Atitude do consumidor frente à irradiação de alimentos. Ciência Tecnologia de Alimentos 2006:26(1):211-213.

Petracci M, Cavani C. Muscle growth and poultry meat quality issues. Nutrients 2012;4(1):1-12.

Sarwar A, Ullah S, Ullah F, Khan M, Ullah W. Effect of Gamma Irradiation on Microbial Quality of Red and Poultry Meat Sold and Processed in Peshawar, Pakistan. European Academic Research 2014;1(12):58515861.

SAS Institute. SAS user's guide. Cary, NC; 2001

Silva ND, Junqueira VCA, Silveira N. Manual de métodos de análise microbiológica de alimentos. $3^{a}$ ed. São Paulo: Varela; 2007. 317 p.

Spolaore AJG., Germano PML, Germano MIS. Irradiação de alimentos. In: Germano PML, Germano MIS. Higiene e vigilância sanitária de alimentos. São Paulo: Livraria Varela; 2001. p. 421-442.

Torgby-Tetteh W, Adu-Gyamfi A, Odai BT, Appiah V. Combined effect of irradiation and frozen storage on survival of viable bacteria and inoculated Escherichia coli in chicken. Journal of Food and Nutrition Sciences 2014;2(3):53-57.

Xião S, Zhang WG, Lee EJ, Ma CW, Ahn DU. Effects of diet, packaging, and irradiation on protein oxidation, lipid oxidation, and color of raw broiler thigh meat during refrigerated storage. Poultry Science 2011;90(6):1348-1357

Zhuang $\mathrm{H}$, Savage EM. Postmortem aging and freezing and thawing storage enhance ability of early deboned chicken pectoralis major muscle to hold added salt water. Poultry Science 2012;91 (5):1203-1209. 
